\title{
TRANSCRIÇÃO DA ENTREVISTA CONCEDIDA POR MIRANDA MARIA ESMERALDA MARTINELLI MAGNOLI
}

\section{ENTREVISTADA POR}

Jonathas Magalhães P. da Silva

Doutor pela FAUUSP, Professor da Faculdade de Arquitetura e Urbanismo da Universidade Anhembi Morumbi.

Data: 24 de março de 2005 


\section{Conteúdos}

- Na entrevista falou-se sobre a trajetória acadêmica e profissional de Miranda Maria Esmeralda Martinelli Magnoli, desde a época do colégio até sua aposentadoria na FAU.

- Destacou-se a história da disciplina de Paisagismo na FAUUSP, assim como a de seus principais agentes e interlocutores.

- Explicitaram-se posturas, procedimentos e conteúdos da disciplina de Paisagismo ao longo de sua história.

\section{Notas}

- A presente transcrição procurou ser o mais fiel possível à linguagem falada pela entrevistada, buscandose intervir somente nas passagens em que houve comprometimento do sentido.

- Todos os comentários do pesquisador estão entre parênteses.

- Para facilitar o entendimento foram acrescentadas ao longo do texto, entre parênteses, explicações julgadas necessárias.

- As notas de rodapé procuraram identificar as pessoas e entidades citadas, além de fornecer as contextualizações necessárias ao entendimento das colocações. 


\section{TRANSCRIÇÃO DA ENTREVISTA CONCEDIDA POR MIRANDA MARIA ESMERALDA MARTINELLI MAGNOLI}

Entrevista concedida a Jonathas Magalhães Pereira da Silva no dia 24 de março de 2005. Esta entrevista é parte integrante da pesquisa de doutorado do entrevistador e revisada em abril de 2006, para publicação na Revista Paisagem e Ambiente: Ensaios, edição especial Miranda Martinelli Magnoli.

Eu não tenho boa memória, mas conheço gente que tem uma memória!!!!!.. Aquele Carvalhinho', que está lá na FAU Maranhão, por exemplo. O Carvalho é uma pessoa que você deveria entrevistar para ter a história do começo da FAU. Eu o conheço, ele é da primeira turma e eu sou da quarta. Nós nos conhecemos desde aquela época. Além de ter de cabeça o próprio documento de fundação da FAU, ele sabe todos os antecedentes que levaram ao que aconteceu.

\section{(...)}

Inclusive ele esteve na primeira turma do Roberto Coelho $^{2}(\ldots)$. Ele se lembra de tudo isso, até porque naquela época a faculdade era muito pequena. (...) Eram 30 alunos por turma. (...) No tempo em que nós entramos - se alguém tinha sido reprovado, perdia a vaga no ano seguinte - não tinha essas matrículas por matéria, era por ano. Era aquele esquema, se ficasse reprovado em duas matérias, você perdia o ano. Isso acontecia e nós ficávamos loucos da vida porque nós perdíamos aquela vaga. Se tivesse dois reprovados, em vez de 30 viravam 28, quer dizer que 30 era o máximo mesmo.

Então a escola era pequena, lá na FAU Maranhão. Não é à toa que a gente ainda tem ligação forte com aquele lugar. Era o lugar da gente. As turmas funcionavam dentro do edifício: só mais tarde, acho que por volta de 64, existiu um galpão. Eu cheguei a dar muita aula ali.

\section{(... por que fez arquitetura?)}

Confesso que eu gostei muito de ter feito arquitetura porque acho que é uma coisa muito interessante, fascinante. Acho muito interessante a história do edifício, apesar de tê-la feito muito pouco, foi bom ter feito. Acho que muitas seriam as áreas que eu acharia interessantes, provavelmente não acharia interessante algo ligado a metalúrgica ou a minério, para o que eu não teria muito jeito.

Como foi que resolvi? A uma certa altura, sem entrar no detalhe, o meu irmão, que é um pouco mais velho, tem três anos a mais que eu, ficou definido que ele faria engenharia. Por uma coisa bastante familiar, bastante da época também - não sei se é verdade ser bastante europeu, talvez não. Mas, em todo o caso, não vou deixar de ser eu, eu sou de uma clara ascendência européia. Na realidade, a irmã menor tem uma certa proteção, do pai, do irmão e depois do marido (risos). 
Acho tive muita sorte nesse sentido. Eu sou ainda de uma geração em que a mulher era ensinada a tocar piano e arrumar um marido de boas condições. Ou, se ela nem tem essa condição de tocar o piano, ela vai se virar em condições piores para arranjar o marido, e pronto (risos).

E eu tive muita sorte no sentido em que meu pai sempre quis que eu tivesse minha profissão, meu trabalho, recordo-me de meu pai falando nisso desde, seguramente, os meus oito anos. $E$ isso foi muito bom e muito excepcional. Até hoje não canso de rever o quanto da minha turma de colégio poucas foram as que seguiram mais adiante. E já tive muita oportunidade de ver como essas mesmas pessoas - ou outras, que nem foram minhas colegas, mas que eram da mesma geração - ressentiram-se muito depois. As pessoas dessa geração chegaram a perceber o quanto isso lhes foi prejudicial. Coisa que provavelmente não foi sentida pelas gerações anteriores.

Mas, então, com essa coisa de que eu iria estudar, teria sempre o apoio do irmão. Era muito engraçado. Veja, antes disso - daí vai precisar dele (refere-se ao irmão) - houve um período, na cabeça de meu pai - nunca na cabeça dele (do irmão) - em que ele iria ser médico.

Bom, se ele seria médico - e veja como a coisa tem a ver com a história da arquitetura, isto é, da relação da arquitetura com a engenharia - se ele iria ser médico, eu seria enfermeira. $\mathrm{Na}$ hora que ficou definido, por questões de meu irmão, que ele faria engenharia, então lembro que minha mãe questionou: "mas agora não tem mais sentido a Miranda ser enfermeira". Era uma coisa tão ligada e tinha uma relação, que você seria auxiliar, em um plano, como a enfermeira para o médico. Então fui ser arquiteta.

Meu pai não sabia o que eu poderia ser. Foi meu irmão que chegou um dia e disse para eu ser arquiteta: um dia ele veio com um livrinho que se usava em nossa época, uma coisa pequena, do Giò Ponti ${ }^{3}$. O Giò Ponti era um arquiteto italiano de Milão, que esteve no Brasil. Ele adorava - Brasil. Ele esteve uns tempos dando palestras na FAU. O livro se chamava La arquitetura e um cristallo. Era um período em que se trabalhava muito com vidro, a transparência do cristal.

Ele (o irmão) também comprou para mim, quando eu ia começar o segundo científico, o Saber ver a arquitetura do Bruno Zevi". A "bichinha" tinha 16 anos e tinha de ler Bruno Zevi, o qual não era nada fácil. Mas realmente, para mim fechou, não é que o Bruno Zevi tivesse ficado claro. Mas por que não (fazer arquitetura) ?!!!

Para você ver como a coisa poderia ter sido outra, fui aluna, no segundo colegial, de um geógrafo que, seguramente, você já ouviu falar - não sei se está vivo ainda hoje - Pasquale Petrone ${ }^{5}$. Fui aluna dele de Geografia, sendo que eu já tinha sido aluna do Jânio Quadros 6 durante seis anos. Todo mundo acha que o Jânio só dava Português, mas ele deu Geografia também. Fui uma ótima aluna do Jânio Quadros, porque fazia parte minha história de estudar no Dante ser ótima aluna (ao longo da entrevista se explicita essa afirmação). Só que o Jânio Quadros realmente como professor era péssimo, porém o conteúdo, entende!!! como conteúdo!!! Quando chega o Pasquale !!! e começa a dar - era Geografia geral - eu queria mudar. Eu queria mudar, eu teria mudado (a opção de ser arquiteta). Por isso que digo a você, eu poderia ter mudado. Acabei não mudando porque a história da arquiteta já estava um pouquinho mais consolidada, estava mais conversada. E eu achei que poderia ser bem interessante, e por outro lado, eu dizia assim: "o que fazer com o diploma de geografia? Dar aula e ganhar mal para burro."

(...)

Eu entrei na FAU em 51, em uma época que ainda era tão ligada a Poli ${ }^{7}$. Ainda era tão recente e tão pequena essa divisão. Não era só recente, era tão relativa essa divisão, que você fazia o vestibular no mesmo dia em que eles faziam para Medicina (acho que Miranda quis dizer Engenharia) e a mesma prova. Só que no dia em que eles faziam Química, que era a única que nós não tínhamos, nós fazíamos Desenho Artístico. 
E, depois, todos os anos das matérias técnicas eram feitas com os professores da Poli, às vezes, inclusive na própria Poli. Resistência dos materiais era feita na Poli. Com os professores da Poli e - uma coisa muito engraçada - com as apostilas da Poli. Eu usei as apostilas de meu irmão, ele era engenheiro civil. Só que como nós tínhamos um número menor de aulas de exatas, e já que eles não faziam um novo programa, como o Mário Franco ${ }^{8}$ sempre fez para vocês, eles simplesmente tiravam um pedaço.

A Faculdade de Arquitetura foi montada claramente, e ficou muitos anos em cima de qual era a atividade profissional (do arquiteto), a atividade pictórica, a atividade que aquela dezenas de pessoas que estiveram na faculdade faziam. O Abelardo de Souza tinha muito trabalho na ocasião; o Eduardo Corona, o Artigas, o Luiz de Mello, o Zenon Lotufo?. Os arquitetos que estavam aí, o que eles faziam no escritório eles ensinavam para a gente. E é o que eles achavam que era a universidade, entende? Então tinha um viés do aprendizado diretamente para o resultado profissional e não era que eles achassem que era somente isso que se tinha para passar. É que (a faculdade) era realmente isso.

Da mesma maneira que a gente tem a Rosinha e o Benê ${ }^{10}$, que continuam dizendo que nós não temos curso de Paisagismo. Acho que nós temos algumas falhas sérias, temos lacunas muito sérias, só que realmente a idéia deles é que você tem de sentar e fazer o projeto do predinho e aí você estará preparado. As dúvidas ao discutir projeto, ao discutir relações do que se traz para cá dos projetos americanos não têm cabimento, não existe na cabeça deles.

Então, veja, se esses professores faziam isso naquela época (refere-se aos pioneiros da década de 1950), tem muita gente fazendo isso ainda hoje. Isso aí, tem muita gente conhecida, que está fazendo ou está querendo que se faça. (...) A Rosinha continua dizendo a toda hora e em todo lugar que se precisa de um curso de Paisagismo. E eu acho muito engraçado. Afinal, quem não é paisagista? A sobrinha do tio que está construindo, e gosta de flor, é paisagista... O outro, que não é arquiteto, é paisagista; o decorador é paisagista. Então eu não sei o que ela quer dizer com isso, que falta o curso.

\section{(... voltando ao início da FAU)}

O Artigas era engenheiro arquiteto da Poli. Na realidade, vem daí a proximidade dele com o Anhaia ${ }^{11}$ e tal... Formado por lá, começou como assistente do Anhaia lá na Poli e foi a partir daí que ele foi para a FAU, onde teve uma ação muito forte. E isso o Carvalho pode lhe dizer. Na fundação da FAU, foi o Anhaia, ele era muito importante para isso.

\section{(... o contexto)}

Com o final da Segunda Guerra cai a ditadura, cai o Estado Novo, cai Vargas, então aí você tem uns 15 anos de alegria muito grande, de uma confiança muito grande, um estímulo muito grande. Era um pouco, dilatando, era como no período Juscelino, sobre o qual você deve ter lido muito. Digamos que ele foi o clímax dessa situação, mas teve antes e depois uma situação de muita crença, de muita alegria, de muita confiança realmente. Podíamos finalmente sair do berço esplêndido, do gigante adormecido.

\section{(... voltando à FAU)}

Não há a menor dúvida: se você ouvir alguém falando que em nosso tempo (início de 1950) o curso era melhor: é uma besteira sem tamanho. Não tinha a menor comparação. $\bigcirc$ curso realmente era fraquinho. Só que nós tínhamos um prazer, um orgulho! E uma coisa que acho que muito nos ajudou - eu até disse isso em aula, há muitos anos, devem até ter achado muito estranho. Disse que nós nos achávamos privilegiadíssimos tendo aqueles professores, aquelas pessoas, pioneiros da arquitetura brasileira. E, é por isso que o Artigas conseguiu tanto. Não é só 
porque ele soubesse fazer bem o discurso. Paulinho ${ }^{12}$ até hoje leva todo mundo no papo. Você sentia que estava ouvindo pessoas que eram capazes para tudo e as quais tinham as melhores respostas possíveis.

Isso, que leva a fazer besteira por causa de sua ingenuidade, ao mesmo tempo facilita que você tenha interesse de fazer, trabalhar, acontecer. Então, havia o trabalho que eles mandavam fazer e não havia o menor esforço (resistência). Eles não precisavam nem falar. Fazia-se questão de fazer o trabalho para que eles passassem na mesa, assim como fazia o Mies ${ }^{13}$ em Harvard.

Lembro-me do próprio Artigas, era o segundo ano que eu era aluna dele, o Abelardo era assistente. Ele deu uma residência para a gente fazer no semestre, e eu estava fazendo acho que em uma escala muito pequena. Era 1:200, daí eu passei para 1:100 e ele queria 1:50. E eu estava me demorando na 1:100, no papel manteiga, ele só passou na minha mesa, vários dias e nunca falou nada. Chegou um dia e ele falou assim: "Se quiser que eu fale alguma coisa, mude de escala". Eu não tive nem dúvida... ( risos)... Ele estava certo de que eu precisava mudar de escala...

(...)

Isso que eu acho que é uma relação entre um período de certas gerações, não foi uma geração, foi uma faixa de gerações, e uma outra faixa, que é bem anterior a vocês ainda (refere-se aqui à década de 80, quando eu cursei a FAU). Eu acho que a coisa melhorou bastante a partir dos anos $80 \ldots$ aquele período de ditadura militar foi muito pesado.

E, por outro lado, nós também tínhamos uma colocação, lembro-me de falar muito isso com a Renina ${ }^{14}$ (...) Estava tudo tão reprimido, estava tudo tão fechado que se tinha algum lugar para que eles (os alunos do período relativo à ditadura militar) tivessem menos reprimidos, era aquele (a FAU). Não existia nem clima para você dizer para o aluno fazer o projeto. $\bigcirc$ que significava fazer um projeto de um unidade habitacional naquela situação? Estão matando as pessoas. Estão matando o Herzog ${ }^{15}$, era uma coisa!!!

\section{(... trabalhos em grupo)}

Na época de aluna não existiam equipes: os trabalhos eram todos individuais. Eu, pessoalmente, acho que tem que ter as duas coisas: o trabalho individual e o em equipe. $\bigcirc$ aprendizado em equipe é um bom aprendizado. Só que acho que as pessoas da equipe têm de ter um controle muito bom sobre como isso funciona. Não é fácil, na vida, todo o dia você vai viver em equipe. Aliás, não é só na arquitetura, você vai praticamente viver em equipe.

Eu comecei a dar aula em meados de 60, mas não em Paisagismo. Eu dei aula com o Abelardo, em Composição de Arquitetura, eram o Abelardo e o Jean, o Maitrejean ${ }^{16}$ que era também assistente do Abelardo. O Abelardo era um pioneiro em relação a chamar gente jovem para dar aula. Ele foi o primeiro a chamar o Maitrejean, que tinha acabado de se formar. E deu um rolo do tamanho de um bonde. Nem todos os colegas deles, arquitetos tão jovens quanto ele, progressistas, e tudo mais, concordaram (...) Ele (Abelardo) ficou insistindo, não chamou outro.

O Abelardo, antes, era assistente do Artigas. No começo havia poucas aulas de Composição de Arquitetura. Urbanismo tinha um ano só. Depois foram ampliando as de Composição de Arquitetura, que passou a ter todos os anos: pequenas composições, grandes composições. $\bigcirc$ Abelardo passou, então, a ter a turma dele. E ele tinha o direito de indicar alguém.

18 Na realidade, naquela época, o catedrático indicava e ponto, está feito. Não se tinha que prestar contas para os outros. $\bigcirc$ Abelardo era uma pessoa muito sociável, muito aberto para traçar idéia, um ser humano excepcional. As pessoas acham que ele era só um fulano gozado, um cariocão. Ele não queria fazer isso (refere-se à escolha do assistente) como imposição por 
ser catedrático. Ele levou meses e não botou outro, como as pessoas queriam que ele pusesse. Até que ele resolveu colocar o Jean como assistente. E o Jean era um bom assistente. Acho que foi um ano e meio antes de eu entrar.

\section{(... se o catedrático era uma figura identificada pelos alunos)}

C catedrático era o dono da cadeira. Para você ter uma idéia, o catedrático era o fulano que chegava, abria a aula, falava algumas coisas e ia embora. $\bigcirc$ responsável direto pela nota era o catedrático. O responsável pelo tipo de trabalho que iria ser feito era o catedrático. E havia uma variação, de um para outro, do quanto ele daria de aula. Mas era claro para os alunos.

\section{(... aulas dos catedráticos)}

O Telemaco ${ }^{17}$, por exemplo, não podíamos dizer que a aula dele não era boa. Nós só podíamos dizer que não entendíamos a aula dele. Ele era uma sumidade, foi uma sumidade internacional. Com aquela história de que nós pegávamos um pedaço das apostilas da Poli, quando chegávamos na aula dele, no terceiro ano, não tínhamos condições. Tínhamos que estudar muito para seguir, e nós não tínhamos tanto interesse. A nossa sorte é que ele tinha um assistente, que até hoje é vivo. Ele tem um livrinho, dois até, quero ver até se eu acho o outro. Chama-se Estrutura da natureza, de Augusto Vasconcelos ${ }^{18}$. Era um livro muito interessante, muito bom, muito claro. Aí ele fazia os exercícios com uma didática impressionante. Aí é que entendíamos aonde o fulano (professor Telemaco) queria ter chegado.

\section{(... ainda quanto às aulas dos catedráticos)}

Tinha uma situação muito variada, por exemplo, o $\mathrm{Cruz}^{19}$, que era o professor de Geometria Descritiva. Era um fulano com quem você não podia falar. Agora, por outro lado, ele era o fulano que dava "A aula". Era incrível. Ele pegava o tecnígrafo, enorme, ia para a lousa e fazia toda aquela descritiva. Eu não entendo como os arquitetos podem não ter aulas de Descritiva há séculos. Eu achava superimportante. Depois o assistente dele, em uma sobra de aula, passava os exercícios para a gente fazer em casa. Compreende como era diferente?

O Abelardo mesmo, o Abelardo ficava muito pouco. Ele decidia o que ia se fazer, quais eram os exercícios, qual era a nota, qual era a linha, mas ficava muito pouco. E ele pessoalmente era contrário, ele achava que arquitetura não se ensinava fazendo palestra. Ele preferia ir mesa por mesa e discutir o projeto com cada um. No que ele não estava muito só não. Eles (os professores) estavam inteiramente por essa linha. Mas a maior parte trabalhava com isso. Havia um ou outro que falava um pouco mais. Mas, fundamentalmente, a Faculdade de Arquitetura foi montada em cima dessa idéia de atendimentos de ateliê, como vocês tiveram.

\section{(...)}

Chamavam-se de pequenas composições e grandes composições. Eram aulas de projeto. Para você ter uma idéia, no primeiro ano eram o Zenon Lotufo e o ĺcaro20. Eles ensinavam o "bê-ábá", até como usar uma trena, como medir, como fazer. E o exercício típico, que tinha a essência da arquitetura moderna, era a cozinha.

A cozinha da arquitetura moderna é uma cozinha que só está na arquitetura moderna. Ela não está em nenhuma outra arquitetura. A cozinha estreita, com toda a medição de quantos passos a pessoa dá. Tudo isso era transmitido e nós desenhávamos a cozinha e aprendíamos a calcular... hoje é de dar risada (risos). Como você pode pedir para uma pessoa ficar calculando os passos: do fogão para pia e depois para lá, etc.

Acho, inclusive, que eles não passavam para a gente essa coisa dita, colocada, como eu disse agora a você: "a essência da arquitetura moderna está aí." 
Mas eles faziam você ter os exercícios, tudo desenhado, superdesenhados. Desenhado no papel manteiga. Desenhado no vegetal. Desenhado no papel canson a nanquim, quer dizer, eram muito exigentes. Talvez acabasse percebendo (os princípios por trás daquelas atividades), por você. Eu não acho que isso era tão franco.

Acho que era um pouco problema do profissional, que não precisa ir muito mais adiante. Pensar qual é o significado que aquilo está tendo, para ter uma linha, para ter desenvolvimento, entende? Porque é muito aleatório você deixar que o aluno perceba...

Eu até acredito que não era claro para todos isso, que tivessem essa percepção de que aquilo era a essência da arquitetura moderna, que dali você poderia pegar e fazer uma aula sobre o movimento da arquitetura moderna. Acho que eles não tinham isso (presente).

Nós não podemos deixar de dar um valor imenso aos pioneiros, eles fundaram a faculdade, não foi fácil. Abrir um negócio não é fácil. Enfrentaram, inclusive, aquele pessoal da Poli, que fez o possível e o impossível para fechar a FAU. Durante anos e anos! Um movimento pesadíssimo!

Deve-se dizer que eles conseguiram envolver os alunos, o corpo discente era muito unido. Isso eu acho uma qualidade, que os pioneiros todos trouxeram. Isso mostra, inclusive, que eles estavam muito estimulados pelo trabalho, isto é, que não era um bico deles. Tudo bem que, naquela época, ganhava-se proporcionalmente melhor, em relação ao que eles podiam ganhar nos escritórios deles. Porque, na realidade, apesar de não serem muitos, eles tinham poucos trabalhos para fazer. Como hoje. Mas também naquela época.

Só havia projetos, no fundo, para aqueles arquitetos. Se você fosse aumentando as turmas, como nós acabamos fazendo, o problema ia acabar aparecendo.

Mas, em relação a eles, o que acho interessante dizer é que, muito provavelmente, esse tempo que eles gastavam com a faculdade - que não era só para dar aula, era para discutir, para fazer reuniões - eles usavam com muito gosto.

Agora, quando eu sinto, de fato, que a coisa começou a mudar, foi quando veio a outra geração. Quem é o primeiro da outra geração que começou a fazer uma mudança?

Nem digo que é o Maitrejean, um bom assistente sem dúvida. Digo que ele foi o primeiro enquanto jovem que o Abelardo colocou.

Mas o cara que entrou para dar realmente outro viés foi o Nestor ${ }^{21}$. Porque o Nestor entrou também recém-formado. E como recém-formado, ele foi fazer sociologia. Mas ele já tinha um outro viés.

Achavam que ele não tinha nem o direito de entrar no mesmo concurso que o Kneese de Mello22. Aquilo foi um escândalo. Todo mundo sabia que o Nestor iria ganhar.

\section{(... a greve contra o Kneese de Mello)}

Ele era da minha turma. Nós nos formamos em 1955 e ele começou a dar aula em 1956. Tanto que em 1955 fizemos um movimento contra o Kneese de Mello. Contra, porque achávamos as aulas dele muito ruins. Ele colocava uns slides e pronto. Vai olhando os slides. E nós não tínhamos paciência, então, resolvemos fazer uma greve pela aula dele. E coitado do Nestor, ele era tão colega quanto todos, porém ele já tinha algo entabulado com o Kneese de Mello. Era o Kneese de Mello que iria indicá-lo. Como ficava se ele entrasse em greve? Aí foi um negócio, não me lembro direito, mas a gente conseguiu que ele não aparecesse tanto.

Mas, para você ver o que eu estou querendo mostrar, o Kneese de Mello até para dar uma aula simples, de graduação de faculdade, não conseguia dizer alguma coisa sobre aqueles slides!!! Apesar de ele ser uma pessoa muito boa, um fulano generoso, um fulano que teve um papel importantíssimo. Um dos caras que mais trabalhou para a formação da profissão de arquiteto 
e para a fundação do IAB. Um dos caras que teve maior peso neste trabalho. E era um fulano muito bom, o que não faz do fulano um bom professor de história. Compreende?

Tudo mudou no ano seguinte (com a entrada do Nestor). Porque se começou, de fato, a pensar o que queria dizer trabalhar em uma Faculdade de Arquitetura. Levou anos para se fazer mudanças. Mas isso é um dos aspectos, que quando as pessoas dizem - gente de meu tempo - que o nosso é que era um curso. Que é isso!!!! (negando a idéia).

(...)

Urbanismo era uma disciplina no $5^{\circ}$ ano, dada pelo professor Anhaia ${ }^{23}$. Eu peguei exatamente o primeiro programa da $\mathrm{FAU}^{24}$. E Paisagismo também era uma disciplina no último ano, Arquitetura Paisagística no $5^{\circ}$ ano. No memorial de titulação do Lauro ${ }^{25}$ isso também está escrito.

\section{(... greve pela contratação de Oscar Niemeyer)}

Nós fizemos uma greve porque a faculdade tinha se proposto contratar o Oscar Niemeyer.

\section{(... se o que estava acontecendo no Rio e em Minas era algo presente)}

Veja, o Rio, teve 10 anos antes a arquitetura moderna. Na realidade, em São Paulo aconteceu 10 anos depois. $\bigcirc$ Abelardo, aliás, vem disso. O Abelardo é carioca. Não é que ele vem diretamente do Rio para dar aula para a gente. Ele já tinha vindo do Rio para trabalhar em São Paulo, para uma firma grande. Não como funcionário, mas para fazer vários projetos e acabou ficando. E ele era um cara da arquitetura carioca, da linha carioca de pensamento.

Na realidade, os cariocas estavam muito mais adiantados. Tinham mais trabalho, e mais gente, inclusive, trabalhando nesta linha.

Quando quisemos contratar o Oscar, a reitoria deu para trás porque ele era comunista. É claro que eles não escreveram isso, mas disseram claramente.

\section{$(\ldots)$}

E foi uma greve, acho que só não entrou o pessoal do Mackenzie. Inclusive parte da Poli entrou em greve com a gente. Cinco meses de greve. Então, o meu primeiro ano...

\section{(... os primeiros professores)}

Quando a faculdade se montou, ela se montou com os professores do primeiro ano. E daí eu não saberia dizer, mas acho que já tinha uma preliminar, já mais ou menos acertada, para o segundo. E o negócio foi sendo naturalmente montado, para você ver como aqueles primeiros professores foram muito rapidamente acertados. Era o pessoal que estava aí. $\bigcirc$ Corona, acho que estava no Rio e veio (para dar aula na FAU). O Hélio Duarte estava na Bahia e veio (para dar aula na FAU). E veja que eles estavam deixando lugares onde não estavam sem trabalhar, estavam bem, inclusive.

Essa greve foi em 195126, eu estava no primeiro ano da faculdade. Quando eu entrei na faculdade, um mundo tinha se aberto para mim em relação à vida que eu tinha, que era muito restrita, muito isolada, muito apressada. Não tínhamos ninguém, não conhecíamos ninguém no Brasil. Tinha a família, uns três, quatro ou cinco gatos pingados. E tínhamos uma vida muito limitada.

A minha vida teve alguns marcos e um desses marcos foi quando entrei na faculdade. (...)

Nessa tal greve, eu estava muito ligada. Primeiro, porque a turma era muito pequena, então todo mundo era muito amigo. As moças eram tratadas com um carinho excepcional, coisa que na época era diferente de agora. Era uma relação muito carinhosa mesmo, muito respeitosa. Nós 
éramos nove sobre 120 (número total de alunos da FAUUSP, na época), todos se conheciam, todos se cuidavam muito. (...)

Casualmente, uma coisa que ajudava muito, no dia-a-dia, e na produção da própria greve, era que eu sabia datilografia. Quer dizer, eu tinha estudado datilografia, apesar de nunca ter trabaIhado com isso. $E$, em uma greve, você tinha que preparar papel até não poder mais. Aquela época era assim: trabalhava-se com aquelas máquinas e depois rodava-se no estêncil. Era o negócio mais primitivo da face da Terra. Então, lá estava a Miranda o dia inteiro datilografando. Isso acabou fazendo com que eu acabasse participando muito da coisa. E, afinal de contas, quem dirigia e resolvia essa greve eram nossos colegas do último ano. Eram aqueles que você olhava para o chão pensando: eu ainda vou chegar lá (risos).

Lembro-me de ouvir desses colegas um questionamento sobre o quanto seria suficiente estar só na faculdade, na medida em que você teria pouca experiência, pouca prática de projeto e de obra. A faculdade era integral, e inclusive aos sábados, no sábado à tarde, em um determinado ano, íamos para os Senai, Senac - não me lembro qual deles - mexer com a parte elétrica, fazer parede.

Então, na realidade, a coisa era você conseguir estagiar. Só que naquela época não era como passou a ser, depois de alguns anos, que fulano faz estágio e ainda ganha alguma coisa. Você tentava conseguir que ele (o arquiteto) deixasse você entrar lá. Que, convenhamos, você perde o tempo dele, ele perde o papel, perde o material. Eu pensava: "como que eu iria conseguir estagiar?"

Aquele trabalho (refere-se ao trabalho comentado no início da entrevista, no qual o catedrático pede para que ela mude de escala) eu pus em minha pranchetinha, em meu papel canson. A cada noite, eu trabalhava um pouquinho. Lembro-me que quando chegou no fim, e dependuraram todos os trabalhos, o professor disse: "a Miranda tirou 10". Eu pensei, agora está fácil, a hora que acabar isso daqui eu vou enrolar e vou sair procurando um estágio (risos).

Para minha grande sorte, passou uma horinha e chegou o Abelardo perguntando: "Você quer fazer estágio?" Eu não sabia nem como eu ia pedir para alguém. Foi como um presente do céu.

Lembro-me que quando entrei (no escritório do Abelardo), o Jean já estava lá. Depois quem foi para lá foi o Jorge Caron. Ele (o Abelardo) estava fazendo o Edifício Nações Unidas.

\section{(... falando de vivência com projeto e obra quando era estudante)}

Isso era uma coisa que a gente fazia muito. Dava um tempo na hora do almoço e a gente saía da FAU para ir ver as obras. Sempre tinha algum colega vendo a obra lá na (praça) Vilaboim, afinal era perto.

\section{(... início da vida docente)}

Todo mundo pensa que fui assistente do Roberto. Eu nunca fui. Trabalhei no escritório do Roberto, fui estagiária no Abelardo e estagiária no escritório Roberto Coelho Cardozo.

Depois eu até saí, mas voltei ao Abelardo. Formei-me. Fiz alguns projetos (com o irmão). Depois eu entrei na prefeitura, naquele negócio das pesquisas do padre Lebret ${ }^{27}$. Ele fez o primeiro levantamento, o SAGMACS: era o escritório aqui em São Paulo que tinha o contrato com a prefeitura.

22 Eu já era formada a essa altura. Eu tinha feito um concurso para entrar na prefeitura. Um concurso que não valeu nada, pois o prefeito seguinte me mandou embora (risos).

Esse contrato foi o primeiro trabalho de levantamento urbanístico, pesquisa urbanística para São Paulo. $\bigcirc$ contrato tinha sido feito para uma sessão, um grupo, da prefeitura acompanhar. Com 
a idéia muito criteriosa, eu entendo, de esse grupo da prefeitura participar e ir aprendendo as coisas para depois ir seguindo. E eu fazia parte desse grupo.

E, em um certo sentido, não foi bem o que eu esperava, porque eu queria entrar nos grupos de pesquisa. Eram quatro ou cinco grupos de pesquisa que tinham engenheiros em geral, havia grupos e subgrupos que iam fazer as pesquisas nas casas e nas ruas. E eu queria entrar em uma dessas pesquisas, mas não conseguia entrar porque o chefe geral era o Mario Laranjeiras de Mendonça e ele disse: "mulher na minha equipe não." (risos). E engraçado que a mulher dele era médica.

Bom, daí fui falar com o fulano do Departamento de Arquitetura, que tinha me indicado e pelo jeito tinha boa impressão ao meu respeito (mais adiante na entrevista fica claro que a indicação tinha sido feita pelo engenherio Maury de Freitas Julião). Ele disse que iria ver. Pelo jeito, ele (Maury Julião) deve ter falado com Mario Laranjeiras de Mendonça e eles encontraram algum lugar onde a mulher pudesse ficar, que não era bem o que eu queria, mas teve outras vantagens.

\section{(... a ligação com edifício)}

Eu queria muito trabalhar com edifícios. Tinha alguns projetos que eu tinha feito, três casas, acho. Uma muito pequenininha, uma mais ou menos. Eu era boa arquiteta.

Teve uma ocasião que até foi muito engraçada. Eu saí uma ocasião do Roberto porque eu queria fazer arquitetura. Eu tinha tido um convite do fulano que havia sido nosso professor. Eu não gostava dele, nem como professor nem das obras. Era o Miguel Badra Júnior ${ }^{28}$. Você deve saber quem é. É aquele pessoal que fez dragagem do rio Tietê por anos. Eles fizeram várias obras de engenharia. E fazia muita construção de edifício lá na Vila Mariana. Na avenida Bernardino de Campos tinha um monte de prédio deles. E o Miguel Badra me convidou para ir trabalhar no escritório - apesar de não gostar da arquitetura que ele fazia - vi ali uma chance de trabalhar em uma obra, aprender construção, com uma firma de engenharia. Era a oportunidade de pegar este lado, que somos mais fracos e dar um jeito. E eu topei.

Eu falei com o Roberto, ele até achou um absurdo, nós estávamos muito bem. Mas expliquei que queria fazer arquitetura. (risos). Quando cheguei lá, o cara me dá um jardim, até que grande. $\bigcirc$ jardim de uma das clientes árabes deles (risos). Ele tinha me chamado por minha experiência no Roberto Cardozo. Havia duas coisas: primeiro que eu não me sentia preparada para fazer. Aliás, eu sempre demorei muito para achar que seria preparada em alguma coisa. Esse é um problema meu, que tenho até hoje. Mas, em segundo lugar, eu tinha saído do Roberto Coelho, onde eu estaria ganhando até menos que no Badra. E eu realmente precisava do dinheiro. Eu realmente precisava. Mas para mim era importante. $O$ Roberto era quem eu respeitava muito para fazer isso (Paisagismo) e era um aprendizado para mim. Aí eu saí para fazer arquitetura de edifício e ele me põe sozinha para fazer um jardim.

Eu não sei, se eu tivesse tido a confiança... Eu nunca achei que foi um erro. Agora digo assim: "por que não fazer aqueles jardins grandes?". Mas não era o que eu queria fazer. Eu queria fazer arquitetura.

Então, perguntei para o Badra: "O que estava previsto para mim?". E ele disse que eram os jardins. Fui embora na mesma hora. Eu expliquei para ele. Fui muito sincera com ele.

(..)

Eu estava fazendo aquelas casas que eu falei, que meu irmão tinha pegado, porque naquela época você não pegava projeto nenhum. Você pegava (projeto e obra) para entregar as chaves. Elas estavam sendo construídas, eu estava seguindo. Eu lembro-me de uma casa que eu tomava dois ônibus para chegar lá. Era muito complicado. Minha mãe ficava preocupada de 
a filha estar junto dos operários. Os operários sempre foram ótimos comigo. Até hoje, tenho uma relação de obra maravilhosa. Mas era tudo mesmo muito complicado.

Eu fiquei um tempo fazendo isso, tentando tocar essas obras. Tentando também ajudar meu pai em umas coisas que ele estava fazendo com terrenos e loteamentos. Sempre fiz (desenhos) para meu pai. Antes era meu irmão e minha mãe, depois eu e minha mãe. Eu fazia os desenhos dos levantamentos topográficos. Ele fazia topografia. E os projetos de loteamento que ele fazia para o pessoal do interior. Então, toda aquela parte de desenho, perfil de rua, gradis, loteamentos, lote por lote, aquela coisa. Por isso é que sabia normografar. Eu já tinha muita prática. Aliás, eram normógrafos muito especiais, uns normógrafos americanos que você montava a letra. Ficava muito lindo.

Quando entrei na faculdade, eu já mexia com normógrafo, tira linhas, tira linhas duplo, enfim, toda essa parte de desenho eu já tinha aprendido no fazer com meu pai. Isso me ajudou muito. E ajudou-me para arrumar os estágios com meus colegas, o fato de eu ser datilógrafa (risos).

\section{$(\ldots)$}

Então, quando eu saí do Badra, fiquei nessas casas, mas nessa ocasião meu pai estava realmente com muitos problemas financeiros. Ele estava também bastante doente. E o que eu ganhava com isso era muito pouco para segurar esse esquema todo.

Eu já tinha, na realidade, (pensado na prefeitura) só que eu tinha até desistido de pensar. Quando me formei, eu tinha procurado a prefeitura para um cargo que era Comissão de Construções Escolares ${ }^{29}$. Você já ouviu falar disso? Era um grupo de prefeitura de arquitetos modernos, o Tibau ${ }^{30}$ era do grupo. Eram coisas ótimas. E eu tinha "encasquetado" (colocado na cabeça) que eu queria entrar lá, que queria fazer aquilo. E tinha tentado ir várias vezes lá na prefeitura falar com um cara que era o chefe da Arquitetura. Pai desse arquiteto... era o Maury Freitas Julião, o pai do Ricardo Julião ${ }^{31}$.

E ele (Maury Julião) era um engenheiro lá, chefe do Departamento de Arquitetura. Sei que fui várias vezes. Esperava naquela sala. Não conseguia falar com ele. E eu ia e voltava até que um dia ele me atendeu. Eu expliquei que estava formada, que tinha sido boa aluna e ele me perguntou: "Quem te mandou?." "Ninguém" (respondi). "Volta amanhã" (foi a resposta). E assim repetia-se toda aquela conversa. "Olha, eu não entendo, você vem aqui, nem me fala qual é a recomendação que você tem" (fala do Maury). Eu não agüentei aquilo e reagi "então a gente só pode se apresentar se tiver recomendação, etc.". Eu acho que ele gostou, então ele me disse: "Está bem, então deixa o endereço que eu vou te procurar".

Olha, eu liguei para mais de ano e ele dizia sempre que não estava tendo (vaga), que não tinha vaga. (...) E foi quando a coisa não só já estava preenchida, mas me parece que já estava começando a declinar também. E eu não fui conseguindo nada. Fui quebrando o galho com os projetos e já não acreditava mais.

Então ele (Maury de Freitas Julião) me ligou e disse... Foi ele inclusive que falou com o Mario Laranjeiras e disse que ele tinha de me pôr na equipe do Lebret. (...) ele me disse que tinha essa coisa muito interessante. E eu já sabia alguma coisa do padre Lebret. O Anhaia ensinava para a gente sobre o padre Lebret. $\bigcirc$ Anhaia era a própria erudição. Com só um ano (de Urbanismo) a gente tinha uma coisa muito superficial, mas todas as coisas importantes o Anhaia trazia.

Por que eu queria ir para a Inglaterra? $\bigcirc$ Anhaia que havia apontado sobre as newtowns, algo novo naquela época. O Anhaia sabia tudo, nesse sentido ele estava sempre up to date.

Então ele (Maury Freitas Julião) me falou que estavam montando uma equipe da prefeitura e poderia me encaixar.

Não tinha dúvida!!! Não tinha dúvida!!! 
Respondeu duas coisas. Eu estava muito feliz por entrar em algo de Urbanismo, já naquela época. E aquilo sempre foi consideradíssimo. Sempre foi um título em meu currículo, para quem sabia o que era. $E$, além disso, acabei ganhando bastante bem, porque a gente acabou entrando, logo depois, em um regime muito apertado, o tempo era muito curto. Eles acabaram exigindo da gente um regime de dedicação exclusiva. Mas essa dedicação exclusiva não era simplesmente que você não deveria fazer trabalho para outros. É que você trabalhava tanto que não teria como fazer outra coisa.

Eu consegui com a minha turma, umas cinco pessoas, jovens, uma delas era o Ricardo Zarattini ${ }^{32}$. Foi lá que o conheci. Ele era estudante da Poli. Ele estava se formando, estava no penúltimo ano ou coisa assim. (A equipe era formada por ...) mais dois estudantes de engenharia e três de arquitetura.

Nós fizemos o primeiro desenho, o primeiro mapa de São Paulo. Não tinha mapa, para indicar para aonde ia a pesquisa de campo. Então, a gente juntou o que tinha naquela ocasião de loteamentos aprovados e montou aquele mapa. E depois, inclusive, acho que tive sorte, pois se não fiquei na pesquisa de campo, que eu queria muito, eu tive a sorte de quando se montaram aqueles gráficos de toda a pesquisa eu estive na tal Seção de Representação Gráfica, o que para um arquiteto pode ser razoável...

Eu tive muito pouca chance. Assisti a algumas reuniões com o Lebret. Assisti a algumas outras com o grupo, com o Laranjeira. Mas eles nem achavam que eu deveria participar. Eu conseguia pegar um canto e assistir. Não conseguia participar de todas as reuniões porque eu tinha de achar um jeito de passar aquilo em gráficos. O que, de uma certa forma, a SAGMACS, a firma do Lebret, já tinha um certo tipo de modelo, para você usar.

Então não era que se tivesse muito que inventar. Eu tinha que adaptar às nossas situações. Mas não era que eu fosse bolar um gráfico novo. Ele (o Lebret) tinha feito algumas coisas novas para a pesquisa em São Paulo.

Eu diria que a coisa mais complicada era o tempo extremamente curto que se teve. A gente trabalhava estupidamente. Isto durou uns cinco a seis meses para mim. Na realidade, um pouco mais, uns oito meses. $O$ que aconteceu foi que casei e fui para Porto Alegre (1958). Quando estava praticamente pronto, quem ficou em meu lugar foi o Celso Lamparelli33. O Celso Lamparelli era ligado à SAGMACS também. Era o pessoal da frente católica.

Eu já tinha interesse por Urbanismo. E quando eu voltei de Porto Alegre já tinha terminado, mas larguei bem no finzinho, peguei praticamente tudo ${ }^{34}$. $\bigcirc$ Celso acho que ficou dois meses, coisa assim.

Então, foi aí que acabei tendo uma experiência interessante dessa parte de Urbanismo. (...) Bom, você deve notar que tenho muito interesse por Urbanismo, Planejamento. Sinto-me bastante bem lidando com pessoas que trabalham com isso.

Do mesmo jeito que eu me sinto bem em uma reunião com o Botti ${ }^{35}$, quando ele faz aquelas reuniões dos prédios com filas de engenheiros. E volta e meia dou palpite porque entendo do que eles estão falando.

Eu continuei a fazer alguma coisa de arquitetura. Quando voltei (de Porto Alegre), fui trabalhar de novo com o Abelardo. Depois ficamos sócios também. Nesse período eu trabalhava meio dia com o Abelardo e meio dia com o Roberto Coelho. Lá mal tinha trabalho para eles. Ganhei um concurso lá (em Porto Alegre), o primeiro concurso de projeto de praça. Eu mal e mal consegui o contrato, com o qual trabalhei muito aqui ainda.

Eles estavam querendo colocar Paisagismo na Faculdade de Arquitetura deles, que era uma faculdade também recente e com essa desculpa desse concurso, e porque eu havia conhecido 
as pessoas, pois tinha procurado as pessoas lá. E ganhei o concurso e acabei conhecendo cada vez mais o Demétrio Ribeiro, a Enilda Ribeiro e o Carlos Fayet ${ }^{36}$. A turma de arquitetos de Porto Alegre era uma turma de três ou quatro gatos pingados. E do ponto de vista de urbanismo, Porto Alegre era uma das áreas mais avançadas do país, eles tinham ótimos trabalhos. Demétrio Ribeiro tinha começado a dar uns cursos de Urbanismo além (do esperado para a época).

Mas eles não tinham trabalho, nem tempo nenhum. $\bigcirc$ governo era muito pobre, o estado era muito pobre. Eles foram até muito sinceros comigo ao falarem dessa dificuldade.

Eles estavam me convidando para dar aula de Paisagismo na Faculdade de Arquitetura.

Aliás, a essa altura, aconteceu que houve uma reunião qualquer. Eu não me lembro. Era um encontro de Arquitetura e Urbanismo em que eles foram receber o Artigas e o Saia ${ }^{37}$, que estavam vindo de São Paulo para participar desse encontro.

O Saia eu já conhecia, pois tinha feito um trabalho com o Nestor e o Vladimir para a comissão do Quarto Centenário ${ }^{38}$. Aqueles desenhos todos do Saia, de 1954 do Ibirapuera, quem fez, aqueles desenhos, foram Nestor, eu e a Rosinha. Foi nosso primeiro trabalho.

Então eu já conhecia bastante o Saia. E o Artigas eu conhecia como professor. E eles foram superfavoráveis (que eu assumisse a disciplina de Paisagismo na FAU-UFRGS). Só que achei que não estava preparada.

\section{$(\ldots)$}

Veja, o Abelardo já tinha me convidado para dar aula na FAU antes de eu casar. Eu tinha dito para ele que não estava preparada. O mesmo ocorreu quando que ele me convidou para assistente e achei que não estava preparada. Ele me convidou na mesma época que ele convidou o Jean.

(...)

Quando eu voltei, passei a trabalhar no Abelardo de novo e com o Roberto, meio período em cada um. E voltei - levei muito tempo para conseguir voltar - para a prefeitura. Era aquele processo que na realidade não podiam ter me mandado embora.

Por mais que tivesse terminado o padre Lebret, eu precisava mais dinheiro do que era possível ganhar no esquema Roberto Coelho e Abelardo. O Abelardo era um pouquinho mais que o Roberto Coelho, mas era um esquema assim: o Abelardo recebia do cliente e passava-me uma parte. Entende? Era uma coisa que eu não sabia nem o quê, nem como, nem quanto. E o Roberto tinha uma coisa mais segura, (ganhava) por hora. Mas era muito pouco. Não é que eles ganhassem muito. Não é que eles estivessem explorando. Eu não acho isso. Então realmente não dava. A história de voltar para a prefeitura tinha um aspecto financeiro muito importante.

Voltei para o Departamento de Urbanismo da Prefeitura Municipal de São Paulo. Rua Florêncio de Abreu, 26. Lembro-me até hoje, do predinho ao lado do Mosteiro de São Bento. Eu durei alguns meses, talvez um ano, mas como mudou... não tinha nada para fazer.

Imagina!! Um Departamento de Urbanismo em uma cidade como esta. Tudo bem que nós estamos falando de 1960, mas você tem conhecimento o suficiente para saber que em 1960 tinha muita coisa para fazer, mas não tinha nada!... (silêncio). Eu já havia visto, dois anos antes, com o Lebret, que nem sequer mapa (da cidade, o departamento) tinha. (...) Eu comecei a entrar em parafuso...

(...)

Daí calhou do Abelardo convidar-me novamente. Quando ele me convidou, pensei, comentei com meus pais, meu marido. Eles me pressionaram muito, e eu topei. E senti uma felicidade de pedir demissão, que era o que eu queria fazer havia tempo. 


\section{(... a formação na escola)}

Eu tinha tido um histórico escolar muito exigente. Quando viemos para o Brasil alguém falou para meu pai que se ele queria uma boa escola, a boa escola seria o Dante Alighieri. Ninguém falou Instituto Roosevelt. Afinal (meu pai) estava perguntando para um italiano!

Ele (o pai) foi lá, no Dante, voltou e disse: "nós não podemos pagar." Então deram uma bolsa para mim e para meu irmão, integral! Desde que fôssemos uma das três primeiras notas da classe. Existiam três medalhinhas: a de ouro, de prata e de bronze. Ou você tirava uma delas ou a bolsa estava perdida. Eu sabia muito bem, não podia ter outra chance.

Lembro-me que teve um ano que tirei a de bronze. (...) Quando tirei a de bronze, minha mãe, no ano seguinte dizia: "Como é que vai ser? Você não vai mais conseguir estudar!" Nunca mais eu tirei a de bronze. Eu tirava a de prata ou a de ouro. Então entrei superbem na faculdade e sempre fui muito boa aluna na faculdade.

(...)

Nessa época as coisas já eram decididas lá no IAB, no escritório do Artigas, quem iria entrar aonde. E eu não tinha passado por essa grelha. $O$ Abelardo tinha acreditado, tinha sido generoso. E eu não fui uma boa assistente dele.

Eu sei que não fui, tinha meio medo de acompanhar os alunos, tinha muito receio. $\bigcirc$ Abelardo também não era uma pessoa para sentar, discutir e fazer. Eu aprendi que se faz diferente, eu não fiz isso com meus assistentes. Devo ter sido muito chata com eles. Eu sei que quando saí, eles devem ter pensado: finalmente saiu... Mas eles também tinham mais segurança.

Eu lembro que, depois de umas duas ou três aulas, perguntei para o Jean porque a gente não tinha uma palestrinha, algo mais teórico no início das aulas. Nós tínhamos duas aulas de atendimento. Aí o Jean me respondeu assim: "quando o Abelardo sair, eu faço." Ele fazia isso. Não era sistemático, a cada duas ou três aulas, ele reunia os alunos e dava as aulinhas dele. E não comunicava ao Abelardo, não discutia. Eu achava isso errado. Ele fez seu espaço com os alunos. E sabe, Abelardo nunca teria negado. E teria até facilitado se tivesse percebido. (...)

(...)

Fiquei com o Abelardo até 1970. A faculdade foi mudando muito nesse tempo, no sentido que em $1964^{39}$ existiu o tal fórum que estabelece as seqüências, que são os tais grupos de disciplinas.

(...)

Tudo vai se ampliando, na medida em que Composição de Arquitetura e Projeto já existiam em todos os anos e já havia, de certa forma, mais professores. Sempre foi mais privilegiada a área de Projeto.

Acho que foi nessa ocasião que Urbanismo se distribuiu em todos os anos. Não tinha professores suficientes, então, se não me engano, foi em 1970 ou em $1969^{40}$ que eu passei a dar uma mão para uma das disciplinas de Urbanismo, cujo professor titular era o Lauro.

Aí já não era mais o catedrático, era o professor titular. Porém o professor titular dava várias aulas, pois não tinha quem desse as aulas. Então essa era uma disciplina que ele seguia muito pouco. Seguia muito pouco no sentido que raramente ele aparecia em aula.

\section{(... a disciplina de Paisagismo)}

As titulações da pós foram sendo montadas gradualmente, e cobrando, gradualmente, cada vez mais das pessoas. E começando-se a exigir que, para existir as disciplinas, seriam necessárias 
determinadas condições mínimas. Então no início, durante um " $X$ " tempo, muito curto, as pessoas podiam se inscrever diretamente para a titulação. E elas viravam titulares, apresentando um trabaIho, fazendo uns exames, coisa assim. Foi o caso do Nestor, do Lauro, do Lúcio Grinover... e... (...)

O que posso te assegurar é que isso foi vindo gradualmente. Até uma certa data você pode se inscrever para a titulação. E a gente teve esses três ou quatro (que se inscreveram). Passam-se mais dois anos, ou coisa assim - era um tempo bastante longo - você pode se inscrever para livre-docência, sem fazer nada antes (refere-se a fazer mestrado ou doutorado como é atualmente). Então você vai pegando a cada abertura um degrau mais baixo.

E em 1973, ou no final de 1972, você deveria inscrever-se para o doutorado e fazer duas disciplinas, que eles acabaram montando, lá na escola. Curtas, bastantes boas até, mas duas disciplinas curtas.

Você tinha de desenvolver uma tese, apresentar um orientador, e nós não sabíamos o que era isso! $\bigcirc$ Júlio Katinsky ${ }^{41}$ também fez nessa ocasião. $\bigcirc$ Nestor era mais ou menos orientador de todos. Ele não conseguia nem olhar para as pessoas. Também! Ele era diretor da faculdade! Além disso, foi durante uma época que ele foi retirar o Rodrigo Lefèvre ${ }^{42}$ lá de dentro do DOPS.

\section{$(\ldots)$}

Então, você veja, foram existindo algumas pessoas como titulares que seguravam um monte de disciplinas, que era a única maneira de você ter a escola. Se a gente não conseguisse montar a escola com as diferentes disciplinas. Se você não tivesse os Lauros para responder por quatro disciplinas ou por oito. Havia pouquíssimas optativas, acho que não tinha na época. $\bigcirc$ Nestor segurando toda a parte do Departamento de História. O Lúcio segurava Desenho Industrial e Programação Visual.

Então, aos poucos, foram se formando livre-docentes, depois chegou a uma certa altura, no final de 1972, que ou você entregava o doutorado ou você estava fora.

\section{$(\ldots)$}

Isso era uma condição contratual. Foi quando o Artigas foi contra todo mundo fazer. E botou fogo no inferno, pois as pessoas não queriam perder por deixar de fazer. Mas ele achava que estava todo mundo agindo de forma pró-imperialista.

Por outro lado, havia uma coisa que você deveria entender de outra maneira: seria muito difícil, a partir de uma certa altura, colocar esses fulanos, que já tinham uma certa idade. Não só isso, mas que eram os profissionais de projeto que estavam aí! Que tinham fundado a faculdade! A uma certa altura você fala para eles: "Olha, você vai fazer as disciplinas como doutorando e eu vou estar nessa banca." Para o Nestor, por exemplo, dizer: "vou estar aí nesta banca para ver se você pode entrar ou não". Então, na realidade, você também tem de se colocar no lugar deles.

Eu me lembro que o Abelardo... Eu disse " $n$ " vezes para ele: "Abelardo, por favor faça." Eu me referia para formação como livre-docente. Ele dizia que não iria se submeter a isso.

(...)

Renina, lembro-me que fez por não querer perder. Mas, a uma certa altura, ela estava louca da vida. Chamou o Benedito Lima de Toledo para ser orientador. Sabe!! E o Benedito?!! Quando ela apareceu com a tese, coitado, ele me disse: "como eu poderia me meter a ser orientador da Renina?" 
E é engraçado, hoje vejo as pessoas dizendo que isso foi pró-forma. Absolutamente, não foi tudo pró-forma. Aquelas teses foram, para as pessoas, na ocasião, tão difíceis quanto elas são agora. No seguinte sentido: tivemos alguns meses para fazer esse trabalho, não tivemos bolsa CNPq, não tivemos biblioteca (a biblioteca era um vigésimo do que está aí), não tínhamos orientador, não cursávamos disciplina. Não tínhamos nada disso. Então aquilo, que hoje eu não aceitaria nem para terminar a graduação, era o que era possível na ocasião.

(...)

E era muita pressão, continuava-se a dar todas as aulas, fazer aquilo e aquilo outro. E lembrome que não tinha nem o tal regime que hoje é considerado, mínimo, o tal turno completo. Era tudo turno parcial. Ou era aquilo ou era o integral. No integral, você não podia fazer nenhum projeto fora, e naquela ocasião era controlado. Então ninguém era integral na faculdade. Acho que tinha um integral na matemática, enfim, não tinha nada a ver com as ciências aplicadas.

Então, o que aconteceu? $\bigcirc$ Roberto Coelho não quis fazer nenhuma dessas coisas, nem a titulação nem a livre-docência. E ele, meu Deus do céu, ele praticamente decidiu que não iria fazer. Ele foi perdendo espaço, quer dizer, o que houve no caso é que todas essas disciplinas foram aumentando (refere-se às disciplinas de Urbanismo, Comunicação Visual e Desenho Industrial) tiveram condições durante um certo período.

Houve até uma folga financeira, por parte da reitoria em relação à faculdade, por ter ganho uma certa maioridade. Quer dizer, quando a gente conseguiu colocar um arquiteto como diretor. $\bigcirc$ Nestor foi diretor, isso deu muita força... Aquela biblioteca... O que o Nestor fez para montar aquela biblioteca, não está escrito.

(...)

Foi quando as diversas áreas foram chamando professores. $\bigcirc$ Roberto continuava perdendo. Em vez de chamar outro, ele foi perdendo. E na realidade, no começo, quando fui aluna dele, iá tinha uma pessoa como assistente. E tinha como assistente a Daisy Igel, uma arquiteta formada em Harvard. Era ela que contava para a gente das aulas do Mies.

Depois da Daisy, ele conseguiu um segundo assistente, do mesmo jeito que o Abelardo. Sabe!. Ele não tinha uma situação pior! Ele conseguiu outra pessoa, acho que foi o Rodolfo Almeida Fernandes, colega nosso de turma. Acho que a ordem é essa, acho que foi o Rodolfo mesmo. Ficou um bom tempo até com ele.

Foi quando começaram a pedir essas titulações. O Rodolfo, sei que foi por causa disso. A Daisy, não sei. Não sei se foi por causa do escritório dela. Ela já tinha escritório. Não estava tão ligada à FAU assim. Acho que ela desistiu. Do Rodolfo, eu sei que ele não queria entrar nessa de titulação e chamou o Antunes ${ }^{43}$.

Ao invés de ele (Roberto Coelho Cardozo) tentar preencher essas vagas, que tinham ficado vazias, ficaram ele e o Antunes. Ele não queria mais ninguém. Eu sempre soube que o doutor Lauro teria insistido muitas vezes para que ele contratasse mais professores e fizesse a bendita titulação. O Lauro insistiu com o Roberto e depois insistiu com o Antunes.

Com o Antunes eu sei, porque assisti. (...) $\bigcirc$ Lauro segurou a nossa disciplina por uns tempos. Institucionalmente, a disciplina ficou porque o Lauro segurou. Não sei se iríamos conseguir montar depois, caso o Lauro não tivesse segurado.

Porque durante uma ocasião não tinha ninguém (para se responsabilizar pela disciplina de Paisagismo). No período que não tinha ninguém, ele reservou um horário da aula dele de Urbanismo. Porque a gente não podia mais ter Paisagismo sem um professor responsável.

(...) 
O Roberto, inclusive, não sei por quantos anos, deu uma mancada com a faculdade, pedindo licença. Durante um tempo, ele conseguiu licença com vencimentos. Parece-me que por muito mais tempo do que seria o razoável. Foi-se dando um jeito, ele estava lá na Inglaterra, de vez em quando ele voltava, ficava andando um tempinho por aí... e ficava o Antunes sozinho.

Só que nessa altura já não era fácil para se conseguir gente nova. (...) Mas ainda tinha alguma chance. Eu estava lá no Planejamento, estudando com o pessoal de Planejamento. Até foi o Gasperini ${ }^{44}$ que falou (para o Lauro): "põe a Miranda para ajudar o Antunes."

Mas antes disso, ele (o Lauro) chegou a procurar o Antunes para falar. Não sei o quanto ele (o Antunes) procurou. Mas consta que ele teria falado com um colega, o Luciano Fiaschii ${ }^{45}$. É um cara ótimo! É o cara que até hoje mais segue a coisa do Roberto. Eu digo que não sei o quanto ele ligou, pelo seguinte: acho que ele não chegou a indicar porque o Luciano me disse que nunca quis (ser professor), de fato tinham falado com ele, mas que nunca se interessou em ser professor. E nunca aceitou (isto foi por volta de 1971).

Eu comecei a ajudar o Antunes, acho que era 1971. Foi quando insisti em falar com ele para que pegássemos mais alguém. Até porque o Roberto já tinha de uma vez desistido. Depois do período longo de licença com vencimentos, ele pegou uma licença sem vencimentos. (...) Se não me engano, em 1979 ele teve de pedir demissão, ou ele voltava e dava as benditas aulas. E daí ele já tinha de fazer o doutorado em um certo tempo, ou ele não voltaria. Foi quando ele resolveu não voltar, porque ele não queria fazer a tese. Ele não queria passar por isso.

Ficou, portanto, o Antunes só. Acho que era 1969. Antunes ficou carregando 150 alunos $^{46}-$ já havia 150 alunos por turma, há muito tempo - e não tinha a menor condição de fazer atendimento com 150 alunos. Você pode fazer as equipes que quiser. E o que ajudava, para desestimulá-lo, e também era causa de ele ter ficado sozinho, é que o Antunes, a cada vez mais, tinha mais interesse pela pintura. $\bigcirc$ Antunes morreu como um pintor. Então, aquela coisa de você se matar para atender 150 alunos, que era impossível, ainda mais quando não se queria aquela coisa.

(...)

Quando chega no final da década de 60, você tem todos os grupos de disciplina com praticamente o mesmo número de professores que se tem hoje. Talvez não seja exatamente isso, mas quase. Depois acabou, não tinha mais nem horário. E quando digo que não tinha mais nem horário. (...)

O Lauro respondia como titular. Ele cedia parte das horas dele, de Urbanismo, para ser dado Paisagismo. E era o Antunes que dava. Ele (o Lauro) podia até não fazer isso, porque ele fez não sei. Quer dizer, já perguntei uma vez isso para ele e ele disse que achava importante Paisagismo e que tinha confiança de que tudo iria dar certo. Ele era da linha inglesa de Paisagismo. Não sei...

\section{(... voltando ao conteúdo na época em que o Roberto Cardozo lecionava)}

Não era propriamente nem jardim nem praça. Eles (Roberto e Daisy) escolhiam algumas situações que pudessem discutir. Eram exercícios bastantes selecionados, nem eram tirados da realidade, eram montados mesmo, irreais. Por meio deles se podia discutir um pouco a implantação, a relação entre lote, rua e sistema. Lembro-me de um trabalho que fizemos sobre lote, rua e sistema de tráfego.

(...)

Eu cheguei a fazer um jardim de cobertura, de laje, coisa assim, mas não era essa coisa batida... tipo pegou Eckbo ${ }^{47}$ e traz aqui. Claro que você tinha uma influência muito grande. Ele era formado na Califórnia com o professor Eckbo e havia estagiado em seu escritório. E essa 
era a linha de pensamento na ocasião. E eu fiz muito isso por causa do escritório dele. Mas na faculdade, não.

Antunes tinha mais dificuldade em selecionar exercícios. Ele fazia muito uma coisa ligada à vegetação, coloração... principalmente quando estava mais ligado à pintura. Alguém que poderia dizer melhor, e que foi aluno dele, é o Silvio. Eu sempre considerei o Antunes, do ponto de vista didático, um dos melhores que já vi na minha vida. Ele tinha uma didática impressionante.

(...)

Ele (o Antunes) vinha dizendo que não queria ninguém, já há algum tempo, sei que ele não queria escolher ninguém por aquilo ser do Roberto. Um dia ele (Roberto) voltaria. Até o dia em que o Roberto acabou pedindo demissão. Mas ele continuou sem querer ninguém e o Lauro dizia: "Escolhe alguém, que eu vou responder". E "necas".

(...)

Gasperini, que era da Comissão de Graduação, veio falar comigo. Perguntou se eu topava sair de onde estava, no Planejamento - porque eu estava muito bem onde estava - para dar uma mão ao Antunes. Ele (o Gasperini) até falou: "Afinal, você trabalha com paisagismo". E eu disse que topava e falei para o Antunes: "Vamos convidar mais alguém."

Eu fiquei com o Antunes, especialmente pelo fato que ele estava na faculdade há muito tempo. Como uma assistente dele, eu achava razoável. Afinal, o fulano estava lá já há alguns anos. E seria ele quem diria qual linha nós iríamos seguir, como iríamos trabalhar, quem iríamos contratar. Até que um dia pressionei, ele falou do Luciano.

(...)

Luciano era recém-formado. Só que nessa altura, na faculdade, já era normal pegar gente jovem. Isso foi complicado lá nos começos, depois não. Quando você olha o quadro da faculdade, foi de gente muito jovem. O próprio Silvio, que ficou como estagiário no começo, e o Sun. Até a Maria Angela ${ }^{48}$ quando entrou era muito jovem também e nem era arquiteta.

que aconteceu é que fiquei dando uma mão para ele (Antunes), acho que 1971 inteiro, e 1972 inteiro, de 1972 tenho certeza, porque o Lauro não dava sossego para nós dois. Nós tínhamos de fazer a tese. E o Antunes sempre dizia que não estava conseguindo fazer, mas que pretendia. Ele sempre colocava que iria entregar. (...) $\bigcirc$ quanto ele estava fazendo, era discutível. Eu nem sei quem teria sido o orientador dele. Não tenho a menor idéia. Eu sei que para mim era o Nestor. Mas não se tinha esta relação (que temos hoje em dia com os orientadores). Como dizia o Julinho ${ }^{49}$, a gente não sabia nem o que era isso.

O que aconteceu foi o seguinte: no final de dezembro, entreguei a minha tese, e o Antunes não entregou. Encontramos na faculdade com o Lauro.

(o Antunes fala) "Eu não tive condição de trabalhar."

(o Lauro fala) "Que condições você acha que ela teve, e ela entregou..."

Quando chegou em março, foi a minha defesa. Fui muito bem na defesa. A minha defesa foi muito melhor que a minha tese (risos). Passa-se não sei se 15 ou 20 dias e recebo uma carta do departamento me convocando a uma reunião para que eu tomasse outras providências.

Eu fui ao departamento perguntar ao Lauro se não era algum engano. Sei lá se não podia ser um erro da secretária, enviando para mim uma carta que deveria ter sido encaminhada ao Antunes. E ele me disse: "Erro nenhum, fui eu que mandei. Quem é a doutora aí? ... É uma questão institucional. Você é a doutora. Você é a responsável. O Antunes infelizmente perdeu a condição de ser responsável." 


\section{$(\ldots)$}

E eu sei que logo depois o Antunes falou, coisa que já vinha falando sempre, que estava cada vez mais ligado com a pintura. E, na realidade, essa coisa de você se demitir não era de um dia para o outro. Ou havia uma brecha?. Houve sim, depois para aqueles que não haviam entregado o doutorado, houve uma brecha para se inscrever nas disciplinas... acho que foi aí que começou o mestrado.

Então, ainda existia uma possibilidade, e alguns fizeram. Eram poucos, mas alguns fizeram. Porque naquela ocasião os Lauros e Nestores da vida, esses que viraram titulares e estavam segurando esse lado institucional, fizeram o máximo para as pessoas conseguirem. Porque era um problema para a faculdade não ter as pessoas.

(...)

Ontunes falou que não estava disposto a fazer isso. Pesou muito o fato de ele estar mais ligado à pintura. Ele disse que estava indo fazer uma exposição na Bahia (...) e que iria dedicar-se à pintura.

(... Miranda insistiu com ele, ele topou ficar algum tempo. Miranda precisava arrumar mais gente).

Só que aí a coisa estava muito difícil. Aí já não havia verba, mesmo!! As coisas tinham mudado muito do ponto de vista financeiro, do governo. E aquela faculdade, em uma determinada época, pegou uma montanha de gente. A FAU passou a ter uma relação professor/aluno muito alta. Por que eles iriam ver aquele caso particular? Eu sinto dizer, mas o Roberto nos prejudicou muito. Muito! É chato dizer, mas ele nos prejudicou muito!

Um dia o Antunes trouxe um quadro para mim e disse: "eu não venho mais".

\section{(... alteração no conteúdo)}

Eu comecei a mudar logo. Quem veio me ajudar em um determinado instante foi o Rittes ${ }^{50}$, antes do Silvinho e do Sun. Aliás, o Silvinho entrou via Rittes. O Silvinho encantou o Rittes. Eu não tinha certeza quanto ao Silvio, mas ele insistiu tanto e o Rittes ficou naquela situação de promessa dada. Porque o Silvinho quando quer uma coisa, ele consegue.

Acho que consegui uma vaga e o Rittes veio. Mas, na realidade, ele não era uma pessoa para a gente. Ele era uma pessoa para Desenho Industrial, coisa assim. E eu não consegui mais a vaga dele (Rittes), pois ele não saiu, foi para outro lugar (dentro da FAU).

O Silvio deve lembrar do Rittes não do Antunes. Ele deve lembrar do Antunes, mas da época em que ele esteve na faculdade, mas acho que não foi aluno do Antunes.

\section{(... sobre Roberto Coelho Cardozo)}

A disciplina realmente começou com o Roberto em 1952 ou 1953. Eu conheço o Roberto já não como professor, quero dizer, ele era professor. Foi muito interessante, conto isso muitas vezes.

Os alunos faziam viagens nas férias. Daquela vez, foi para as cidades de Minas. Em outra ocasião, fomos a Recife. Para Recife foi o Fracarolli51 (acompanhando os alunos). Sempre tinha ir um professor acompanhando porque teoricamente era uma viagem com os alunos da faculdade.

$E$, no do $3^{\circ}$ ano da faculdade, fomos, em julho, para as cidades mineiras. E o professor que foi nos acompanhando foi o Roberto Coelho Cardozo. Ele estava curiosíssimo por conhecer as cidades mineiras, conhecer os alunos, estar com os alunos. E foi tão marcante para mim. Não me lembro em que trecho, nós estávamos de trem. Nós estávamos indo, já não me lembro de que pedaço a que pedaço. Não sei se era de Belo Horizonte a Ouro Preto. 
Mas lembro ainda que ele estava em uma janela de trem, e eu também. Parece tão distante e olha que tenho péssima memória. Mas lembro dele vendo a paisagem. Aquela montanha, aquela pedra. A paisagem mineira é muito típica, é muito própria. E ele seguia colocando perguntas para mim. Perguntas como quem está fazendo você refletir: por que isso é assim? Não que se você tivesse lido algum livro você saberia a resposta, mas ele perguntava: "por que é assim, o que você acha que aconteceu para formar isso?"; "por que razão tem uma erosão ali?". Eu pensava; "Onde esse cara foi inventar essas coisas?"; "Como que passa pela cabeça dele esse tipo de questão?". Eu ouvi com ele, pela primeira vez naquela época, questões que hoje estão falando sobre a proteção do meio ambiente. Evidentemente eu não entendia na época. Achava aquilo tudo muito estranho. Estranho!!! Estranho!!! Muito esquisito, mas muito interessante!!! (risos).

Tanto que, no ano seguinte, eu fui pedir para trabalhar lá. Pedi para trabalhar com ele. Eu fiquei com aquele negócio na cabeça.

(...)

Eu achava ele incrível por essa maneira de pensar - uma forma de pensar que ele já vinha elaborando. E nós não tínhamos muita chance de questionar, de refletir e de nos colocarmos.

\section{(... perceber a topografia)}

Aliás, isso era uma coisa que a gente procurou fazer logo na FAU. Fazer (os alunos) relacionarem os morros com cotas de rua, coisas assim - um problema que tínhamos, inclusive, no trabalho.

Eu me lembro de a gente ter recebido um arquiteto, bem conhecido, para quem a gente ia fazer o jardim do prédio, o acesso. E ele não tinha reparado que a garagem dele estava em uma cota completamente diferente da rua. A cota estava, aproximadamente, com dois andares de diferença.

Porque, afinal, naquela época, a prefeitura não pedia cota de rua. E os arquitetos nem olhavam. No fundo, na França, a arquitetura moderna de Le Corbusier era um terreno plano. Você fica procurando o terreno plano aqui...

(...)

Eu diria até, que de um certa forma, (essa experiência com os alunos) foi um ensaio distante que você chegou a ver. Eram as caixas de areia; aquilo foi bolado pelo Sun. Mas acho que quando a gente começou, na base dos papéis e das curvas com o Rittes, a trabalhar essas formas, lembrome que era uma coisa que me chamava a atenção e que estávamos cobrando isso de nossos alunos. E eu costumava a dizer que tínhamos de conseguir com que os alunos olhassem aquilo e vissem subir ou descer (o terreno). Eles tinham de enxergar. Mais de uma vez eu vi chegar professores de outra área que não viam nada. É porque eles não lidavam com aquilo...

(...)

Eu me lembro de outro exercício interessante, em que era dado um estacionamento no qual você tinha que colocar " $X$ " veículos. E você tinha de sombrear com um certo número de árvores dadas. Era um jogo. No entanto, o que se queria introduzir era um trabalho com formas do terreno; um trabalho com declividade que o veículo usaria; um trabalho com sombreamentos diferentes. Então, os alunos começavam a perceber que se estamos no sul, não adiantava arborizar.

\section{(... quando a disciplina passa do $4^{\circ}$ para o $1^{\circ}$ ano)}

Foi um grande esforço passar para o 1- (ano). Achei fundamental passar para $\circ 1^{\circ}$ ano. Porque quando os alunos chegavam no 4, eles já chegavam "colados" pelos professores de Urbanismo que Paisagismo era para plantar repolho. 
(... de onde vem essa distorção, uma vez que desde a época do Roberto a disciplina não tinha esse caráter?)

Ignorância pura. Inclusive de colegas que foram alunos do Roberto e os quais poderiam perceber. Eu acho que, inclusive, os nossos colegas arquitetos, o próprio Jean, quando representante da faculdade no Crea. Eu soube pelo José Luiz Fleury ${ }^{52}$, não soube por ele. Já havia disciplina de Paisagismo na faculdade, quando no Crea apareceu umas das tantas discussões se Paisagismo deveria ser feito por arquiteto ou por agrônomo. O que para o Crea é um problema, pois o Crea responde pelos dois lados. Ele (Maitrejean) foi o fulano que ficou de fazer o parecer.

Eu soube depois. Foi o Fleury que me trouxe, pois ele substituiu o Jean e olhando coisas da gestão anterior ele deu com daquilo. Ele (Maitrejean) apresentou um arrazoado dando para o agrônomo. Então, sabe, você pega um fulano aberto, esclarecido. $\bigcirc$ Jean é um fulano muito inteligente.

\section{(... características da formação das primeiras turmas)}

Nós praticamente só aprendemos a fazer o projeto do edifício. De Urbanismo tivemos algumas pinceladas, muito boas, porque o Anhaia Mello era uma pessoa que conhecia muito o assunto. Ele tinha muita clareza das coisas. Mas nunca fizemos nada em Urbanismo. Nós assistíamos a aulas teóricas sobre o Urbanismo na Inglaterra, que era o que ele considerava mais adiantado.

(...)

Para você ter uma idéia, por exemplo, eu saí (da FAU) de tal forma que podia fazer com bastante facilidade um levantamento topográfico de uma coisa relativamente limitada. Eu sabia chegar na rua, pegar o teodolito e fazer. Eu não sei se a coisa hoje é tão prática. Eu fazia, não porque meu pai era topógrafo, aliás, a minha menor nota era de Topografia, ele (pai) achava uma tristeza. Mas eu podia fazer isso. Podia fazer projeto, apresentar na prefeitura. Podia fazer cálculo estrutural, podia fazer os projetos de hidráulica, elétrica, bolar minha fundação sem muito problema. Esse tipo de preparo para você dar uma resposta ao mercado, era de uma relação direta.

\section{(... o quanto a formação da graduação deve ater-se ao mercado)}

Quando começamos a achar que se deveria sair (para atender o mercado), foi um negócio muito discutido. Havia várias discussões sobre qual é o perfil de arquiteto que se queria. Eu me lembro de uma ocasião quando nos cobraram - aliás eu estava dando aula com o Jean ainda, e foi quando tivemos clareza de que não era por aí - que estávamos deixando de dar as coisas de acordo com a legislação existente, os recuos mínimos, etc. E que os alunos saíam sem saber. Mas foi daí que percebemos que ao tentar introduzir essas questões, estaríamos reduzindo o exercício a um jogo de encaixe. $\bigcirc$ exercício ficava tão amarrado, tão limitado. E começamos a fazer o contrário, daí deliberadamente.

O que sentíamos muito sobre essa questão do mercado é que, sem dúvida, o curso foi se afastando cada vez mais do projeto do mercado. Mas o projeto do mercado também foi mudando bastante. (...)

Houve até uma ocasião em que um aluno - boa cabeça, líder - colocou que para o aluno sair preparado ele deveria sair da faculdade tendo feito um projeto de cada tema e programa que poderia acontecer na vida. (espanto!!) E não é que isso foi posto como: "Veja que absurdo".

34 negócio é conseguir pensar na coisa e não ter uma experiência de tudo para que se possa repetir, ampliar ou ajeitar aquela experiência. E, de uma certa forma, diria que o grosso de nós achava que - isso era bastante dito - com três a seis meses de escritório você aprendia (o que o mercado exige). 


\section{(... preparando o aluno para o mercado de trabalho, sobre o Benedito Abbud)}

Similar a isso é um problema com o Benê, que foi nosso assistente e era professor na PUC-Campinas antes. E ele era um bom professor, querido pelos alunos, uma pessoa muito agradável. E muito inteligente.

O Benê acabou saindo da escola por um outro motivo, mas isso era um problema sério que tínhamos dentro dessa linha. Ele discutia muito comigo por causa disso. E depois de alguns anos ele me disse que teria continuado a discutir (risos). Ele não mudou de idéia.

Mas quando ele entrou na FAU, era sócio da Suely Suely Suchodolski. Era ela que tinha o grosso dos trabalhos. Depois não me lembro o que aconteceu na vida particular da Suely que ela acabou viajando e fechando o escritório.

E o Benê se sentiu muito desprevenido. E como ele, por mais sócio que fosse, sentia-se em uma situação secundária, pois ela que pegava, ela que discutia... Ele se desvalorizou muito, achando que não iria conseguir. Eu lembro que a essa altura ele já era nosso assistente, e também da PUC-Campinas.

Eu conversava muito com ele, de que ele iria conseguir pegar trabalhos, etc. E acabou aparecendo uma coisa pequenininha, uma outra... Eu mesma peguei um trabalho que me foi oferecido pelo Blossfeld ${ }^{53}$, aquele botânico.

Aliás, foi muito engraçado quando o Blossfeld telefonou para mim para fazer um projeto. E o Blossfeld era um fulano, "o botânico". E já o conhecia bastante. Tinha muito respeito por ele. Mas ele sempre me deixou muito claro que plantas eram com ele. Eu tomava muito cuidado para falar com ele, também, era um cara mais de idade. (...) Mas o que ele deixou muito claro era que, em um terreno ruim, com muita declividade, tinha de fazer caminhos, etc. E que precisava de um projeto mesmo. E ele não podia fazer tudo aquilo. E ele gostaria que eu concordasse com que ele fizesse comigo a parte de plantação.

Eu pensei, pensei, e depois telefonei para ele - já estava muito envolvida em montar a disciplina, sabia que não iria ter tempo. Acho que já estava em tempo integral, não me recordo - e telefonei dizendo que iria indicar um fulano muito bom, que ficasse tranqüilo, que se tivesse algum problema eu iria nas reuniões. E passei para o Benê.

Ele foi pegando cada vez mais trabalhos e passou a dedicar-se somente ao escritório, que, aliás, é um sucesso. Ele é um sujeito muito capaz, mas, vamos e venhamos, ele é também um sucesso empresarial, ele sabe fazer a coisa.

Eu gosto muito dele, mas tinha esse problema da linha (pedagógica ligada ao mercado).

(..)

Uma das mudanças que fiz de cara. Você estava me perguntando sobre as alterações. E eu disse de cara: "nesta Escola se trabalha com o espaço público". Isso foi a mudança inicial. E foi uma discussão. Aliás, não teve muita discussão porque Silvio e Sun não discutiam isso comigo. E quem mais entrou? Bom, você sabe que Rosinha e $\mathrm{Chace}^{54}$ não entraram porque não quiseram. Então não precisava muito para convencê-los (refere-se a Silvio, Sun e os outros).

Mas com o Benê, a coisa foi realmente barra pesada. E principalmente quando ele já estava com o escritório dele, onde, querendo ou não, só tinha trabalho particular. Você tem alguma coisa agora pelo Brasil afora, naquela ocasião nem sei se tinha. Isso tudo é mais recente. Antes era tudo do Burle ${ }^{55}$ e pronto. Eu e a Rosinha ainda fizemos algumas coisas juntas. Mas você pega meu currículo e o currículo dela - enorme - e vê que a grande maioria é particular também.

E o Benê dizia que os alunos estavam saindo despreparados para enfrentar a vida profissional, porque os serviços que haviam não era esse, do espaço público. 
Essa linha que você fala das faculdades particulares é justamente esta. E a minha colocação para ele (Benedito) era que estávamos em uma universidade pública, então iríamos estudar o espaço público, que era o que se deveria fazer. Antes de mais nada, deveríamos dar atenção ao espaço público.

E, do ponto de vista do mercado, o fulano que souber fazer um projeto para o espaço público, faz assim (estala os dedos) com o espaço particular. Disso estou convencida até hoje. Eu não tenho a menor dúvida.

Eu até diria... não chego a dizer que o espaço público é mais difícil que o espaço particular... por ter mais situações, ter mais diversidade. Nem quero saber se ele é mais difícil. Se o fulano aprendeu a fazer o projeto, ele aprendeu a refletir, aprendeu a lidar com a hipótese, aprendeu a lidar com processos. E vai se utilizar desses processos, meu Deus do céu!

Eu acho muito tacanha essa colocação, de que tem que se adequar ao mercado. Isso é para a escola técnica.

\section{(... planejamento da paisagem)}

Um grande engano específico é achar - e isso é o que sempre foi vendido, é o que vem na história das couves e dos repolhos - é achar que paisagismo é fazer jardinzinho. Não é isso que estamos pretendendo, a gente pode até fazer, mas não é isso.

Acho, inclusive, que temos um problema serí́ssimo, que nesses anos todos, não conseguimos que Paisagismo entrasse no Planejamento. Nós não conseguimos. E não temos feito os esforços necessários. As disciplinas da faculdade não facilitam isso. $\bigcirc$ grosso dos professores não está convencido disso.

O Silvio mesmo, na USP, pediu-me para mandar um trabalho (para expor na Bienal de Arquitetura). Eu perguntei se podia apresentar o trabalho da subprefeitura da Lapa, e ele me disse que não, que não daria certo, que não tinha grande interesse, que não dava bons desenhos. (...) Então não mandei.

\section{(... não olhar o mercado presente, até porque ele se transforma, amplia-se)}

Nós temos de fazer o mercado.

Tem uma coisa importante. Eu falei dos pioneiros da faculdade. Uma coisa que a gente perdeu, eu não sei bem o porquê. Isso não fez parte da vida de vocês, mas fez parte da minha. Eu vi isso acontecer. Essa gente que abriu a faculdade, e havia também outros, mas principalmente essa gente: eles abriram o mercado. Fez com que se dissesse: "precisa-se do arquiteto". Então eu diria que com o que eles conseguiram fazer, naquela época, nós realmente tivemos muito pouco sucesso.

Porque temos uma porcentagem baixíssima (de edificações, de espaços) feita por arquitetos. $\bigcirc$ grosso não é de arquiteto. Se você ver as condições que temos agora, é muito mais difícil, mas a profissão de arquiteto é muito mais conhecida, é muito mais reconhecida. Quando eu fiz o tal concurso da prefeitura municipal de São Paulo, fiz concurso para engenheiro. Não existia nem vaga para engenheiro-arquiteto. E não conseguimos ampliar mais.

Veja, o Silvio não teve interesse em expor na Bienal (o trabalho da subprefeitura da Lapa). E sei que ele me respeita muito. Um negócio que eu teria de trabalhar para pôr sobre a Regional de Lapa: "como usar o paisagismo dentro de um plano de urbanismo".

No entanto, para minha grande alegria, aquela moça que vende a revista da Pós, lá na FAUMaranhão, a Lina me disse: "Não é um conhecido seu, um professor, que tem o trabalho na Pós n. 13." (...) Era o artigo do Emmanuel ${ }^{56}$, que eu tinha relido, inclusive, para entender. 
○ que não está claro? Por que as pessoas não estão percebendo? $\bigcirc$ que está hermético demais?

Nós não sabemos valorizar isso em nosso grupo, pois essa moça me disse que estavam vendendo a Pós 13, porque alguém soube no Rio Grande do Sul e tinha comprado. Escreveram para lá. Pediram para mandar a revista para o Rio Grande do Sul. E esse fulano escreveu para alguém no Rio de Janeiro. $O$ Rio de Janeiro pediu a revista. $E$, mas não sei que outro lugar pediu também.

E o trabalho dele, de que se trata? É inserir a paisagem no planejamento. É um mercado que não abrimos. E estamos brigando pelo jardinzinho?

Não estamos nem trabalhando na universidade. $O$ trabalho do Paulo Pellegrino ${ }^{57}$, que eu saiba, não é isso. Não é pegar o plano diretor ou as subprefeituras, não é isso (com que o Paulo Pellegrino está trabalhando).

(O Paulo está trabalhando). É uma abordagem que ou você entra com todo o meio ambiente, toda a ecologia ou você não entra. E temos um problemão para entrar. A ecologia até é muito bom, mas aí vão entrar todos os engenheiros e todo esse povo que está cuidando de gestão ambiental.

A quantidade de arquitetos envolvidos é muito pequena. Inclusive, dificilmente o arquiteto coordena, dificilmente ele tem um papel importante. $\bigcirc$ grosso, que vi na Secretaria Municipal de Meio Ambiente, é esse pessoal que brinca com química. Uma vez eu disse, quase me botaram para fora pela janela, que deveríamos começar a repensar esses EIA-RIMA ${ }^{58}$, que estavam todos feitos errados, em que o pessoal fica brincando de quanto tem de cloro.

\section{(... retoma-se a conversa falando da formação do Grupo de Disciplinas de Paisagismo - GDPA)}

Por muitos anos fomos da disciplina de Planejamento/Paisagismo. Mesmo para a pós, tínhamos dificuldade de conseguir vaga, porque estávamos no bolo de Planejamento. E o grosso das vagas, o pessoal de Planejamento pegava para eles e nós ficávamos com o resto.

O que acontece é que, na medida em que o Roberto não se propôs a ampliar a disciplina de Paisagismo quando se montaram as seqüências das demais disciplinas (a mudança para "grupo de disciplinas" foi só uma mudança de nomes), o Paisagismo ficou dentro do que era Planejamento. E pouco aparecia na ocasião, porque a disciplina era dele, o Roberto tinha o espaço dele. As seqüências dos grupos de disciplinas foram se consolidando cada vez mais, tendo suas representações nos conselhos. À medida que iam se montando as articulações, iam se montando esses quadros decisórios.

Quando me tornei responsável, eu era responsável pelo grupo de disciplina de Planejamento. Então, eu passava o tempo e ia a reuniões com os meus colegas de Planejamento. A turma dos Lauros, dos Cândidos da vida (...)

Então, veja, até me aposentar, eu ia a todas as reuniões por uma razão muito simples - esse foi o ônus que nossa área teve em relação às demais - Paisagismo se tornou uma área despreparada. Como não houve gente antes, também não teve gente fazendo titulação. Compreende? Então, quando chamei Silvio, Sun, etc., chamei todos recém-formados. Ao passo que os outros iá tinham os seus doutores.

Então os outros também conseguiam, do ponto de vista institucional, com um certo poderio, inclusive, mandar para as diversas reuniões, gente diferente. Mas Miranda ia para tudo, reunião do conselho, reunião da CPG, reunião... eu só vivia em reunião, porque eu era a única pessoa que tinha o título necessário para ir, o de doutor. Independentemente de depois eu ter tido outras pessoas para ajudar. Isso levou muito tempo. Eu lembro desse tempo porque eu só fazia isso, tentar montar essa coisa. E eu também era a única orientadora por dezenas de anos. 
Então, quando você fala da visão do Urbanismo, essas coisas. Na medida em que eu estava dentro do Grupo de Disciplinas de Planejamento, senti que precisava (participar das reuniões), até para acompanhar todas essas discussões. E até para conseguir coisas que eu quisesse. $E$ realmente era bem chato. Então, eu tinha de poder discutir com eles, tinha de conhecer o que estavam falando. Tinha de estudar, lembro-me do período em que tinha de estudar aquele negócio chato para burro. Eu não tinha aprendido nada dessas coisas na graduação. Eu ia lendo planejamento. Então, essa coisa toda, para mim, foi muito boa. Eu acho bom.

Quando a gente virou um grupo de disciplinas (de Paisagismo), eu me lembro, a gente já estava trabalhando bastante, meio isolados, mas ainda respondíamos dentro de tudo isso. Daí foi uma jogada, que não achei interessante, que o pessoal de Planejamento fez. Na verdade, que o Lauro fez.

Nós já tínhamos um número de professores suficientes para começar a pesar nas votações. Foi político! Foi político!

Até um certo momento, tínhamos tão pouca gente, tínhamos tão poucas condições, que de uma certa forma tínhamos que jogar com eles. Era difícil conseguir, por mais que eu reclamasse.

Inclusive, teve uma vez em que ele me chamou na sala dele, no departamento. E eu perguntei: "Por que está me chamando para um assunto que você vai colocar no conselho?" E ele me responde: "Porque eu já aprendi, eu quero acertar antes com você, como você vai agir. Porque eu não quero que você reclame, lá na hora."

Eu poderia reclamar, mas na hora que ele falasse "Agora vamos votar", eu perderia. Só que eu poderia pôr em discussão aonde ele estava querendo chegar e daí também não interessava para ele. Então foi essa coisa até depois que me aposentei, quando de repente o pessoal me disse: "Ah! nós viramos um grupo de disciplinas".

(...)

Mas, veja, quando o Lauro soltou, era porque a gente já estava conseguindo ter gente. Gente titulada. Gente nas diferentes reuniões. Eles tinham de trabalhar conosco. De repente poderíamos votar com os outros. Então era melhor soltá-los (pensou o grupo de Planejamento), pois, na hora em que você os solta, eles (o grupo de Paisagismo) são bastantes fracos. Dentro dos diferentes grupos que ali estão.

\section{(... quando fica presente o Desenho Urbano e o Planejamento se transforma)}

Pegou uma moda. Os americanos abriram especificamente Urban Design. Aqui não se abriu o Urban Design. Agora, os americanos que começaram a fazer o Urban Design. Anos atrás, tinha vários artigos em revistas de Landscape Architecture, quer dizer, quem fazia Urban Design. Para - Landscape Architecture, americano, em geral, apesar de lhes faltar trabalho - eles têm muito, mas também têm muita gente - isso acabou por não interessar mais, porque eles se interessavam muito mais por fazer os parques, por fazer os trabalhos de manejos, etc.

Inclusive, o Landscape teve um período inicial, na depressão, em 1929, que lhes ajudou muito na formação - eles tiveram um apoio muito grande com os parques florestais, estaduais e nacionais, que montaram naquela época.

Tanto se xingam em nossas unidades de conservação, o pessoal só fala mal. Elas têm problemas; só que tem uma coisa, a unidade de conservação foi chupada do modelo americano. Já o modelo americano, do ponto de vista de recreação - semanal, quinzenal, mensal ou anual - funciona!!!. É um país muito motorizado, no qual as pessoas estão muito acostumadas a viajar muito. É por isso que você pode dizer que eles são muito bem montados, sim senhor. Não tem luxo nenhum. Não é nada consumista. É tudo muito asséptico, mas é tudo, há dezenas de anos, cuidado. 
E isso ainda veio com a depressão de 1929, o Landscape Architecture trabalhou muito com engenheiro florestal. Foi quando, inclusive, ampliou-se a coisa. Então, eles têm outros âmbitos lá. Agora, no começo, lá pelos anos 40 e 50, eles faziam muito Urban Design.

Aliás, muitos cursos de Urban Design saíram de cursos de Landscape Architecture. $\bigcirc$ próprio curso de Chicago se formou assim.

Eu não sei como está agora na FAU, mas isso eu diria que já tinha começado antes. Eu me lembro de algumas discussões em que eles falavam em planejamento setorial. Achava muito engraçado. Por que seria setorial, pegar um pedaço de cidade?! Mas para outros já era uma coisa com cara de Desenho Urbano.

Eu também diria que um bom arquiteto de edifício deveria fazer um bom desenho urbano. É que se você pegar um arquiteto de edifício americano, iá não faz. Eles só fazem o edifício e pronto. Muitos de nossos também, só fazem o edifício e pronto.

(... apesar de passadas algumas horas, a conversa ainda continuou por alguns minutos. Fui embora levando comigo as imagens, os instantes. Decisões, opções, lutas, perseguições, conquistas. Diaa-dia, passo a passo. Sem caminhos claros, sem respostas claras. $O$ acaso brincando com nossos desejos, com nossas crenças. $\bigcirc$ querer e a curiosidade conduzindo as ações, as idéias.)

\section{Notas}

(1) Refere-se ao arquiteto Vicente de Paulo de Carvalho Collet e Silva, formado em 1953, na primeira turma da FAUUSP.

(2) Refere-se ao professor Roberto Coelho Cardozo, o primeiro professor de Paisagismo da FAUUSP.

(3) Arquiteto e designer italiano nascido em 18 de novembro de 1891, formado na Politécnica de Milão em 1921. Em 1928 fundou a revista Domus. Lina Bo Bardi trabalhou no início de sua carreira em seu escritório em Milão na década de 1940.

(4) Bruno Zevi nasceu em 1918. Em 1948, publicou Saber ver a arquitetura. A primeira edição brasileira dessa obra só se concretizou em 1978, com a editora Martins Fontes.

(5) Professor doutor da Faculdade de Geografia da USP. Estudou e lecionou no Colégio Dante Alighieri. Ingressou na Faculdade de Geografia em 1944.

(6) Jânio da Silva Quadros, nasceu em Campo Grande em 25 de janeiro de 1917, presidente do Brasil entre 31 de janeiro e 25 de agosto de 1961.

(7) Escola Politécnica da Universidade de São Paulo.

(8) Refere-se ao professor Mário Franco, da Escola Politécnica, que lecionou para os alunos da FAUUSP.

(9) Refere-se aos arquitetos Abelardo Riedy de Souza, Eduardo Corona, João Batista Vilanova Artigas, Luiz Ignácio de Anhaia Mello e Zenon Lotufo.

(10) Refere-se aos arquitetos Rosa Grena Kliass e Benedito Abbud, ambos ex-presidentes da Associação Brasileira de Arquitetos Paisagistas - ABAP.

(11) Refere-se ao professor Luiz Ignácio de Anhaia Mello.

(12) Refere-se ao professor Paulo A. Mendes da Rocha.

(13) Refere-se ao arquiteto Mies Van der Rohe.

(14) Refere-se à professora Renina Katz Pedreira.

(15) Refere-se ao jornalista Vladimir Herzog, diretor de jornalismo da TV Cultura, torturado e assassinado em 25 de outubro de 1975 pelo governo militar.

(16) Refere-se ao professor Jon Andoni Vergareche Maitrejean.

(17) Refere-se ao professor Telemaco Hipolito de M. Vanlangendonck.

(18) Refere-se ao professor Augusto Carlos de Vasconcelos.

(19) Refere-se ao professor Pedro Moacyr do Amaral Cruz.

(20) Refere-se aos professores Zenon Lotufo e Ícaro de Castro Melo.

(21) Refere-se ao professor Nestor Goulart Reis Filho.

(22) Refere-se ao professor Eduardo Augusto Kneese de Mello. 
(23) Refere-se ao professor Luiz Ignácio de Anhaia Mello.

(24) O primeiro programa da FAUUSP está transcrito logo depois desta entrevista. Foi retirado de BIRKHOLZ, Lauro Bastos \& NOGUEIRA, Brenno Cyrino. A FAUUSP, sua criação e funcionamento na Vila Penteado. São Paulo: FAUUSP, 1991.

(25) Refere-se ao professor Lauro Bastos Birkholz.

(26) Existe uma inconsistência de datas, pois enquanto a doutora Miranda afirma que a greve se deu em seu primeiro ano de faculdade, portanto em 1951, o doutor Lauro Birkholz cita a greve como sendo no 1- semestre de 1950.

(27) Refere-se a Joseph Lebret (1897 - 1966), dominicano, que funda em 1947 o escritório SAGMACS - Sociedade de Análises Gráficas e Mecanográficas Aplicadas aos Complexos Sociais, que prestou serviços para a prefeitura de São Paulo entre 1956 e 1958.

(28) Engenheiro arquiteto Miguel Badra Júnior. Tem como uma de suas obras de destaque a sede da Eaesp-FGV, na avenida 9 de Julho, em São Paulo. Publicada na revista Acrópole, n. 275, em outubro de 1961.

(29) Refere-se à comissão montada a partir do Convênio Escola que "foi um acordo firmado entre a prefeitura Municipal e o Estado, que se uniram para dar cumprimento às determinações da constituição de 1946, que obrigava União, Estado e Municípios a investirem uma porcentagem mínima dos recursos arrecadados na educação primária. O arquiteto Hélio Duarte (1906-1989) foi membro dessa Comissão desde o seu início. Os arquitetos da escola carioca, integrantes da Comissão, trazem para São Paulo o clima de discussão existente na Escola Nacional de Arquitetura, recém-desvinculada da Escola de Belas Artes do Rio de Janeiro". Retirado do texto intitulado "Influências das linhas pedagógicas sobre o ensino de projeto". SILVA, Jonathas Magalhães. In: Anais Projetar, 2003.

(30) Refere-se ao professor Roberto José Goulart Tibau.

(31) Refere-se ao engenheiro Maury Freitas Julião, que foi professor da Escola Politécnica da USP e seu filho, arquiteto Ricardo Augusto Leite Julião.

(32) Refere-se a Ricardo Zarattini Filho, banido do território nacional em 6 de setembro de 1969 na luta contra o regime militar e anistiado em 31 de agosto de 1971.

(33) Refere-se ao professor Celso Monteiro Lamparelli.

(34) Realmente, o contrato com a SAGMACS termina em 1958, ano em que a professora Miranda vai para Porto Alegre.

(35) Refere-se ao arquiteto Alberto Rubens Botti.

(36) Refere-se aos arquitetos Demétrio Ribeiro (1916 a 2003), Enilda Ribeiro e Carlos Maximiliano Fayet, todos, professores da então recém-criada, em 1952, Faculdade de Arquitetura e Urbanismo da Universidade Federal do Rio Grande do Sul, pela fusão dos cursos de Arquitetura do Instituto de Belas Artes (IBA) e da Faculdade de Engenharia.

(37) Refere-se aos arquitetos João Batista Vilanova Artigas e Luís Saia.

(38) Luís Saia com Vilanova Artigas, Sergio Milliet e outros, fizeram parte do Conselho de Administração do Museu de Arte Moderna - MAM.

(39) Refere-se à portaria GR n. 122, de 25 de novembro de 1963, com reflexos no 1ำ semestre de 1964.

(40) É bom lembrar que nessa época $(1969,1970)$ alguns professores foram afastados, por questões políticas, da faculdade.

(41) Refere-se ao professor Júlio Roberto Katinsky.

(42) Refere-se ao professor Rodrigo Brotero Lefèvre. Militante da Ação de Libertação Nacional, foi preso em 1970, em São Paulo, passando por sucessivos interrogatórios na Oban e no DOPS. Aguardou o julgamento no prédio Tiradentes, sendo libertado em 1971. Morre em 1984, de acidente de automóvel, na Guiné-Bissau.

(43) Refere-se ao professor Antonio Augusto Antunes Neto.

(44) Refere-se ao professor Gian Carlo Gasperini.

(45) Refere-se ao arquiteto Luciano Fiaschi, ex-presidente, entre 1985 e 1986, da Associação Brasileira de Arquitetos Paisagistas - ABAP, criada em 1976.

(46) Miranda deve estar se referindo ao aumento de alunos ocorrido na FAU, passando de 30 para 40 alunos, e em especial à turma de 1964, com 67 alunos, e os 27 alunos extras conseguiram o direito de cursar a FAU por meio de uma liminar. Dados colhidos de depoimentos com os arquitetos Ricardo Guerra Florez e Michail Lieders, os quais estudaram na FAUUSP entre 1964 e 1969.

(47) Refere-se a Garrett Eckbo, arquiteto paisagista norte-americano.

40 (48) Refere-se aos professores Silvio Soares Macedo, Sun Alex e Maria Angela Faggin Pereira Leite.

(49) Refere-se ao professor Júlio Roberto Katinsky.

(50) Refere-se ao professor Augusto Rittes Garcia.

(51) Deve estar se referindo ao professor Caetano Fracarolli. 
(52) Refere-se ao professor José Luiz Ferreira Fleury de Oliveira.

(53) Refere-se ao botânico Harry Blossfeld, autor do livro Jardinagem. São Paulo: Melhoramentos, 1965.

(54) Refere-se aos arquitetos Rosa Grena Kliass e Fernando Magalhães Chacel.

(55) Refere-se ao paisagista Roberto Burle Marx.

(56) Refere-se a Emmanuel Antonio dos Santos, que publicou o artigo "Por que planejar com a paisagem?", Pós, Revista do Programa de Pós-Graduação em Arquitetura e Urbanismo da FAUUSP, n. 13, junho de 2003.

(57) Refere-se ao professor Paulo Renato Mesquita Pellegrino, do Grupo Disciplinas Paisagem Ambiente (GDPA), do Departamento de Projeto da FAUUSP.

(58) EIA - Estudo de Impacto Ambiental; RIMA - Relatório de Impacto Ambiental. 